\title{
急勾配移動床流れにおける河床波の形状，伝播特性 \\ DYNAMIC AND KINEMATIC FEATURES OF \\ SAND WAVES IN UPPER REGIME
}

\author{
福 岡 捷 二*. 奥 津 一 夫** - 山 坂 昌 成*** \\ By Shoji FUKUOKA, Kazuo OKUTSU and Masashige YAMASAKA
}

\section{1. 序}

土砂, 砂砶など洗掘, 堆積が可能な材料で河床が構成 されている移動床上には, 流れの水理条件や河床材料の 特性に忘じて異なった河床形態が生じる. 河床波が発生 すると流砂量や流れの抵抗が変化し, この変化は, 逆に 河床波の形状を変化させることになる.このように，移 動床上の流れでは河床形態, 流砂量, 抵抗則は相互に強 い結びつきをもつ一つの系としてとらえなければならな い. そのためには河床形態, 流砂量, 抵抗則の一つひと つを十分に理解する必要がある. 特に, 河床形態は流れ の抵抗則を強く支配するもので, 河川工学上重要であ る.

河床形態に関する研究の歷史は古く, 土砂水理学の中 心課題となってきた. アメリカ土木学会1および日本土 木学会 ${ }^{2}$ においてこの基本的課題の調査研究が行われ， わが国では 1971 年水理委員会内に移動床流れの河床形 態と粗度の小委員会が設置された. 河床形態の研究部会 では, 河床形態の名称, 河床形態の発生機構と領域区 分, 河床波の構造と形状特性ならびに河床波上の流れの 特性について研究の調査が行われ, その後の移動林流れ の研究のための指導書的役割を果たしてきた. しかしな がら, 力学的・運動学的な面からの河床波の解明は, 必 ずしも十分とはいえない. 特に, lower flow regimeに 比して upper flow regime の河床波の研究は極端に少 なく, 流れと土砂輸送の激しさ, 強い非定常性のゆえ に，ほとんど解明されていないのが現状である. 前記ア メリカ土木学会委員会報告の中では，反砂堆（Antidunes）について次のように述べられている.

\footnotetext{
* 正会員 Ph.D. 工博 東京工業大学助教授 工学部土木工 学科

** 正会員 工修 鹿島建設 (株)

*** 学生会員 工修 東京工業大学大学院博士課程 土木工学 専攻
}

“水面波と河床波の位相が砂堆の場合と反対であるこ とからこの名前がつけられている. 反砂堆には流れと河 床波の特性に応じて, 上流へ移動, 下流へ移動, および ほとんど動かないものの三通りの場合がある. 反砂堆上 の表面波の波高は，反砂堆のそれより大きい. 高い速度 とフルード数で表面波は不安定となり, 上流方向へ動き ながら砕波するまで大きくなる．砕波に伴ら擋乱が，区 砂堆を消滅させ, 反砂堆の発生・成長・消滅の過程が繰 り返される.より低い流速では, 表面波は砕波すること なく, 反砂堆は成長と減衰を繰り返す. 反砂堆の縦断形 は, 大きなフルード数での正弦波形から三角形状まで変 化する. 実験水路でのみ，鋭い頂部の三角形状をした下 流に移動する反砂堆がみられる”。この記述は, 定義と しては適切であるが, 力学的・運動学的観点からさらに 深い反砂堆の検討が必要である.

急流河川または扇状地河川では水流が激しく，土砂生 産量が多いため土砂災害が多く，その潜在的な破壊力か らみて, 土砂輸送, 流れの抵抗に関係する upper flow regime の河床波の研究は重要である. 本研究では,

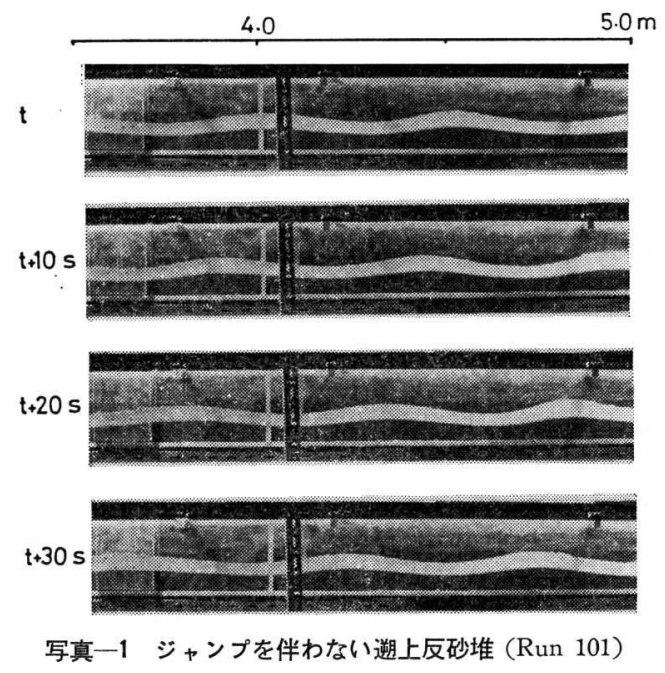



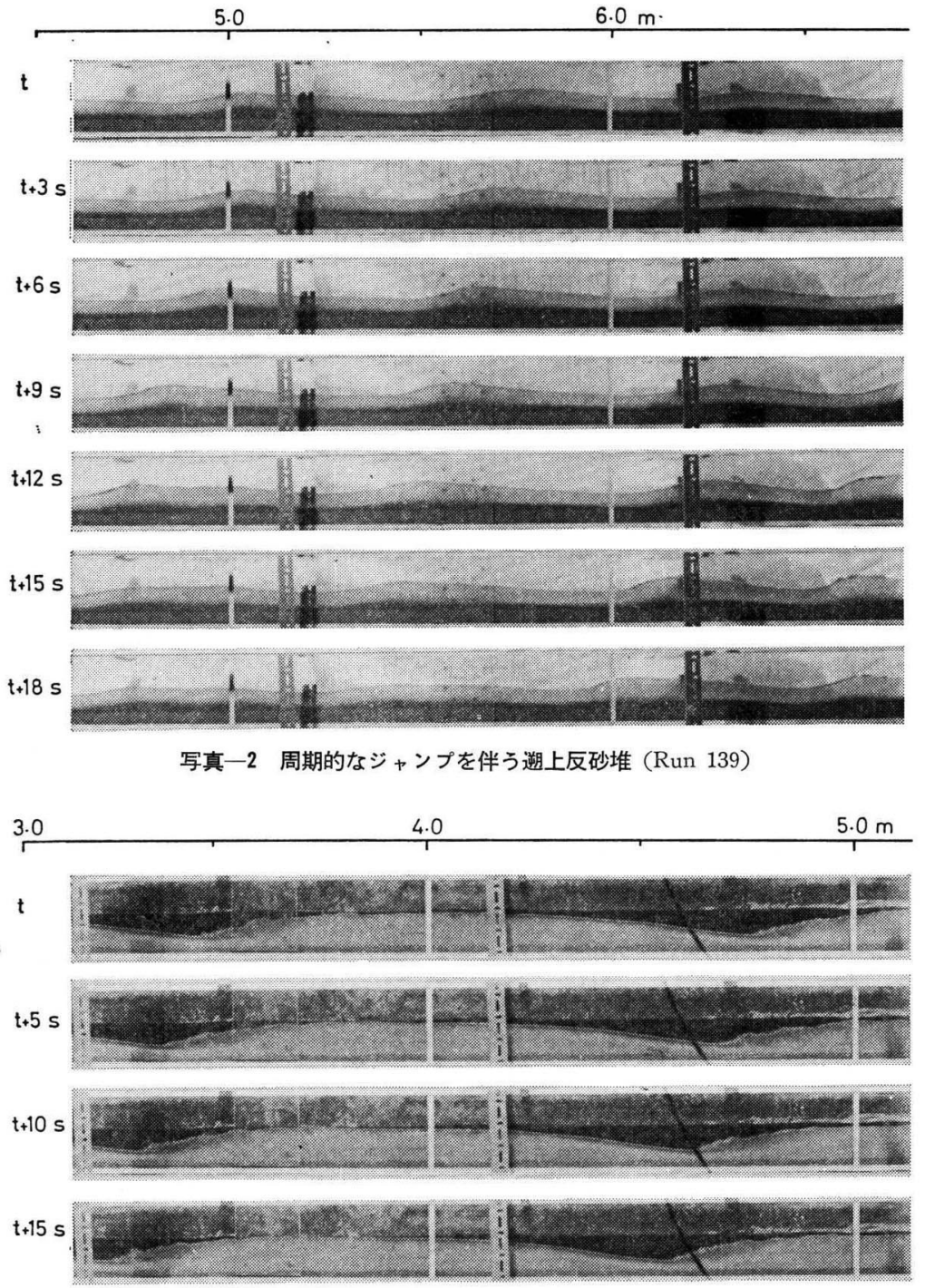

写真一3 Chutes \& Pools (Run 140)

\section{2. 実験装置と実験方法}

自然界でみられる河床波は多く の場合三次元的な形状と運動特性 をもっ.しかし，三次元形状を有 する河床波の特性と挙動は極端に 複雑であり, 十分に制御された実 験なしには三次元河床波の力学 的・運動学的特性を解明するのは 困難である. 現在, upper flow regime の二次元的な河床波でさ えも十分に理解されているわけで はなく, 三次元河床波の理解を容 易にするためにも二次元河床波の 特性を知る必要がある. 二次元河 床波は水路幅方向の流れおよび砂 粒子の運動を拘束することにより 発生させることができる.用いた 水路は可変勾配型の極端に狭い アクリル製の水路で幅 $4 \mathrm{~cm}$, 梁 さ $20 \mathrm{~cm}$, 長さ $8 \mathrm{~m}$ の大きさを もつ ${ }^{3)}$. 水路上流端に 給砂装置を 有し, 通水中, 平均河床勾配が変 化しないように給砂し，実験を行 った．実験には図一1に示す粒径 加積曲線をもつ 4 種類の砂を用い た. 砂の比重はいずれも 2.65 で あり, A, B, C, D 砂の平均粒径 はそれぞれ $0.19 \mathrm{~mm}, 0.76 \mathrm{~mm}$ ， $1.60 \mathrm{~mm}, 0.40 \mathrm{~mm}$ である.

ジャンプを伴う反砂堆や $\mathrm{Chu}$. tes \& Pools の河床波では, 流路

upper flow regime に属する下流に移動する反砂堆, 上流に移動する反砂堆, Chutes \& Pools の力学的, 運 動学的特性を解明することを主目的として二次元実験を 行った.

前述のように, 反砂堆はその移動方向によって上流に 移動する反砂堆（または 遡上反砂堆), 下流に移動する 反砂堆とよぶことが多いが，ここではより簡潔な名称と してそれぞれ遡上反砂堆, 流下反砂堆とよぶことにす る.上流に移動する反砂堆には, 流れのフルード数の大 きさの順に, ジャンプを伴わないもの（写真一1），ほぼ 周期的にジャンプを起こしながら遡上するもの（写真一 2), 常にジャンプを伴って遡上するもの（写真一3）の 3 種類が存在する. 本研究では前二者を遡上反砂堆, 後者 をChutes \& Pools とよび区別し論ずる.
内にジャンプによる水の貯留が起こるため流量が一定と は限らない. したがって平均流量は下流端で測定した数 回の流量の平均より求めた. 流砂量は水路下流端で数波

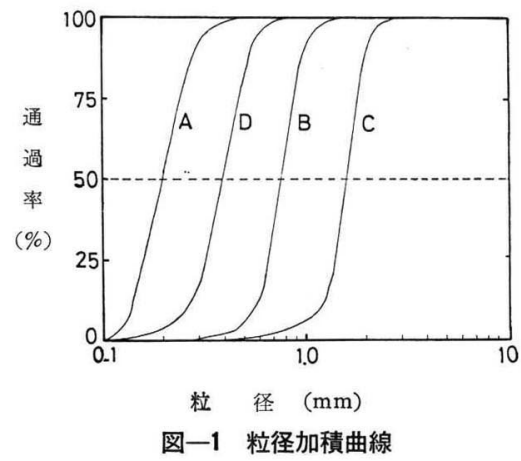


長の河床波が通過するときの量と時間を測定し求めた. 流下反砂堆ではいずれの実験ケースにおいても, 二波長 分の流砂量を採取すれば十分な精度で流砂量を測定でき る. 一方, 遡上反砂堆や Chutes \& Pools については, 河床波が上流へ移動するため河床波数波長分だけ測定す ればよいといらわけにいかず，そのため，できるだけ長 時間流砂の採取を行い, 流砂量を求めた. 水面形状と河 床形状は河床波が十分に発達しきってからモータードラ イブ付 $35 \mathrm{~mm}$ カメラで連続撮影し, これより水面波と
河床波の位相差, 河床波の波長, 波高, 流速, 水面形 状，水深などを測定する.ささら詳しい水面波と河床波 の測定は $8 \mathrm{~mm}$ 映画撮影フィルムを解析し求めた.

実験条件, 測定值, 河床形態をまとめたものを 表一1 に示す. 河床波は二次元的であるため波長, 波高, 波速 などは十分な精度で測定が可能である. 波長は crest to crest 法で測定した. 平均水深 $h_{0}$ は, 河床波の山部の 水深と谷部の水深の平均值で定義した. 本文では便宜 上, 測定位置の原点 $x=0$ は上流端にとられている.

表一1 実 験 条 件

\begin{tabular}{|c|c|c|c|c|c|c|c|c|c|c|}
\hline $\begin{array}{l}\text { Run } \\
\text { No. }\end{array}$ & $\begin{array}{c}\text { 勾配 } \\
I\end{array}$ & 砂種 & 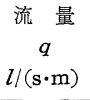 & $\begin{array}{c}\text { 流砂量 } \\
q_{B} \\
l /(\mathrm{s} \cdot \mathrm{m})\end{array}$ & $\begin{array}{c}\text { 平均水深 } \\
h_{0} \\
\mathrm{~cm}\end{array}$ & $\begin{array}{c}\text { 平均流速 } \\
v_{0} \\
\mathrm{~cm} / \mathrm{s}\end{array}$ & $\begin{array}{c}F_{r^{\prime}} \text { 数 } \\
v_{0} / \sqrt{g h_{0}}\end{array}$ & $\begin{array}{c}\text { 波 }{ }^{\text {長 }} \\
\mathrm{cm}\end{array}$ & $\begin{array}{l}\text { 波 速 } \\
C \\
\mathrm{~cm} / \mathrm{s}\end{array}$ & 河 床 形 態, 乞 の 他 \\
\hline 1 & \multirow{3}{*}{$1 / 49$} & A & 36.5 & 0.242 & 4.0 & 91 & 1.5 & 69 & -1.5 & Jump を伴う遡上反砂堆 \\
\hline 2 & & A & 18.3 & 0.121 & 2.7 & 68 & 1.3 & 49 & -1.1 & " \\
\hline 3 & & A & 42.0 & 0.340 & 4.5 & 93 & 1.4 & 78 & -1.4 & " \\
\hline 4 & \multirow{5}{*}{$1 / 147$} & A & 11.5 & 0.0018 & 3.44 & 33.4 & 0.58 & 9.2 & 0.07 & \\
\hline 5 & & A & 37.5 & 0.025 & 6.06 & 61.9 & 0.80 & - & - & 平坦河床 \\
\hline 6 & & $\mathrm{C}$ & 43.8 & 0.0029 & 7.11 & 61.5 & 0.74 & - & - & " \\
\hline 7 & & B & 10.0 & - & 2.90 & 34.5 & 0.65 & - & - & \multirow[b]{2}{*}{ 砂 } \\
\hline 8 & & B & 43.0 & 0.020 & 7.67 & 56.1 & 0.65 & 25.2 & 0.78 & \\
\hline 9 & \multirow{6}{*}{$1 / 64$} & A & 21.5 & 0.063 & 3.42 & 62.9 & 1.09 & 43 & -1.2 & \multirow{3}{*}{$\begin{array}{l}\text { 遡上反砂堆 } \\
\text { ”弱い Jump を時々起こす } \\
\text { 流下反砂堆 }\end{array}$} \\
\hline 10 & & A & 45.5 & 0.132 & 5.38 & 84.6 & 1.16 & 69 & -2.0 & \\
\hline 11 & & B & 24.0 & 0.031 & $\begin{array}{c}4.35 \\
(3.95)\end{array}$ & $\begin{array}{c}55.2 \\
(60.0)\end{array}$ & $\begin{array}{c}0.85 \\
(0.95)\end{array}$ & 17 & 1.0 & \\
\hline 12 & & B & 44.8 & 0.050 & $\begin{array}{c}6.43 \\
(5.90)\end{array}$ & $\begin{array}{c}69.6 \\
(77.6)\end{array}$ & $\begin{array}{c}0.88 \\
(0.97)\end{array}$ & 25 & 0.78 & " \\
\hline 13 & & $\mathrm{C}$ & 14.3 & 0.0099 & 2.75 & 51.8 & 1.00 & - & - & 平坦河床 \\
\hline 14 & & $\mathrm{C}$ & 44.8 & 0.040 & $\begin{array}{c}5.77 \\
(5.20)\end{array}$ & $\begin{array}{c}77.6 \\
(84.0)\end{array}$ & $\begin{array}{c}1.03 \\
(1.10)\end{array}$ & 22 & 1.6 & 流下反砂堆 \\
\hline 15 & \multirow{6}{*}{$1 / 31$} & $\mathrm{C}$ & 9.0 & 0.053 & 1.52 & 59.2 & 1.53 & - & - & \multirow{6}{*}{$\begin{array}{l}\text { 平坦河床 or 流下 } \\
\text { 流下反砂堆 } \\
\text { 遡上反砂堆 } \\
\text { Chutes \& Pools } \\
\text { 平坦河床 } \\
\quad \text { " }\end{array}$} \\
\hline 16 & & $\mathrm{C}$ & 30.3 & 0.104 & 3.55 & 85.2 & 1.44 & 22 & 2.3 & \\
\hline 17 & & A & 10.8 & 0.117 & 2.12 & 50.7 & 1.11 & 57 & -0.81 & \\
\hline 18 & & A & 26.8 & 0.272 & 3.63 & 73.7 & 1.24 & 150 & -1.7 & \\
\hline 19 & & B & 13.5 & 0.116 & 1.89 & 71.4 & 1.66 & - & - & \\
\hline 20 & & B & 39.5 & 0.232 & 3.74 & 106 & 1.74 & - & - & \\
\hline 21 & \multirow{5}{*}{$1 / 20$} & B & 38.0 & 0.418 & 3.2 & 119 & 2.12 & - & - & \multirow{5}{*}{$\begin{array}{c}\text { 平坦河床 } \\
" \\
\text { Chutes \& Pools } \\
\text { " }\end{array}$} \\
\hline 22 & & $\mathrm{C}$ & 15.0 & 0.152 & 2.2 & 68.2 & 1.47 & - & - & \\
\hline 23 & & $\mathrm{C}$ & 34.0 & 0.351 & 3.7 & 91.9 & 1.53 & - & - & \\
\hline 24 & & A & 13.3 & 0.315 & 3.5 & 37.9 & 0.65 & 78 & -0.92 & \\
\hline 25 & & A & 7.8 & 0.131 & 1.99 & 38.9 & 0.88 & 48 & -0.67 & \\
\hline 26 & \multirow{7}{*}{$1 / 73$} & A & 7.5 & 0.0071 & 2.15 & 34.9 & 0.76 & 9.1 & 0.16 & \multirow{7}{*}{$\begin{array}{l}\text { 流下反砂堆, やゃ三次元的 } \\
\text { 遡上反砂堆, 平坦河床に近い } \\
\text { 遡上反砂堆, 弱い Jump を時々起こす } \\
\text { 流下反砂堆 }\end{array}$} \\
\hline 27 & & A & 13.0 & - & 2.62 & 49.6 & 0.98 & 33 & -1.1 & \\
\hline 28 & & A & 26.0 & 0.064 & 3.96 & 65.7 & 1.05 & 41 & -0.59 & \\
\hline 29 & & B & 20.8 & 0.020 & $\begin{array}{c}3.58 \\
(3.38)\end{array}$ & $\begin{array}{c}58.0 \\
(61.5)\end{array}$ & $\begin{array}{c}0.98 \\
(1.07)\end{array}$ & 16 & 0.50 & \\
\hline 30 & & B & 44.3 & 0.047 & $\begin{array}{c}6.35 \\
(5.80)\end{array}$ & $\begin{array}{c}69.7 \\
(76.4)\end{array}$ & $\begin{array}{c}0.88 \\
(0.97)\end{array}$ & 23 & 0.76 & \\
\hline 31 & & $\mathrm{C}$ & 21.5 & 0.013 & 3.86 & 55.7 & 0.91 & - & - & \\
\hline 32 & & C & 44.5 & 0.029 & $\begin{array}{c}6.09 \\
(5.51) \\
\end{array}$ & $\begin{array}{r}73.1 \\
(80.8) \\
\end{array}$ & $\begin{array}{c}0.95 \\
(1.05)\end{array}$ & 24 & 1.2 & \\
\hline 101 & \multirow{2}{*}{$1 / 42$} & $\mathrm{D}$ & 28.3 & 0.164 & 2.45 & 115.5 & 2.36 & 51.3 & -1.14 & \multirow{2}{*}{ 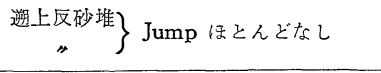 } \\
\hline 102 & & $D$ & 17.3 & 0.110 & 1.72 & 100.6 & 2.45 & 49.4 & -1.16 & \\
\hline 103 & \multirow{3}{*}{$1 / 59$} & $\mathrm{D}$ & 8.5 & 0.037 & 1.75 & 48.6 & 1.16 & - & - & 平坦河床 \\
\hline 104 & & $\mathrm{D}$ & 25.3 & 0.092 & 3.75 & 67.5 & 1.11 & - & - & $"$ \\
\hline 105 & & D & 44.3 & 0.112 & 5.10 & 86.8 & 1.23 & - & - & $"$ \\
\hline 106 & \multirow{3}{*}{$1 / 73$} & D & 37.3 & 0.094 & 5.02 & 74.3 & 1.06 & - & - & \multirow{3}{*}{$\begin{array}{l}\text { 平坦 河床 } \\
\quad " \\
\text { 流下反砂堆, やや三次元的 }\end{array}$} \\
\hline 107 & & $\mathrm{D}$ & 43.3 & 0.070 & 5.94 & 72.9 & 0.96 & - & - & \\
\hline 108 & & $\mathrm{D}$ & 4.0 & 0.0076 & $\begin{array}{l}1.34 \\
(1.21)\end{array}$ & $\begin{array}{c}29.9 \\
(33.0)\end{array}$ & $\begin{array}{c}0.82 \\
(0.96)\end{array}$ & 7.0 & 0.30 & \\
\hline
\end{tabular}


（表-1 つづき）

\begin{tabular}{|c|c|c|c|c|c|c|c|c|c|c|}
\hline 109 & \multirow{12}{*}{$1 / 84$} & $\mathrm{D}$ & 7.5 & 0.0085 & $\begin{array}{l}1.88 \\
(1.70)\end{array}$ & $\begin{array}{c}39.9 \\
(44.0)\end{array}$ & $\begin{array}{c}0.93 \\
(1.03)\end{array}$ & 9.1 & 0.41 & 流下反砂堆, やや三次元的 \\
\hline 110 & & $\mathrm{D}$ & 23.0 & 0.049 & 3.56 & 64.6 & 1.09 & - & - & 平坦河床 \\
\hline 111 & & A & 9.0 & 0.0082 & $\begin{array}{c}2.09 \\
(1.89)\end{array}$ & $\begin{array}{l}43.1 \\
(47.1)\end{array}$ & $\begin{array}{l}0.95 \\
(1.05)\end{array}$ & 10.0 & 0.28 & 流下反砂堆, やや三次元的 \\
\hline 112 & & A & 40.0 & 0.080 & 5.48 & 73.0 & 1.00 & 32.3 & -0.07 & 平坦河床 or 遡上反砂堆 \\
\hline 113 & & B & 9.0 & 0.010 & $\begin{array}{l}2.12 \\
(1.95)\end{array}$ & $\begin{array}{c}42.5 \\
(47.5)\end{array}$ & $\begin{array}{l}0.93 \\
(1.03)\end{array}$ & 9.3 & 0.63 & 流下反砂堆 \\
\hline 114 & & B & 20.5 & 0.020 & $\begin{array}{c}3.76 \\
(3.50)\end{array}$ & $\begin{array}{c}54.5 \\
(58.3)\end{array}$ & $\begin{array}{l}0.90 \\
(1.00)\end{array}$ & 14.0 & 0.53 & $"$ \\
\hline 115 & & B & 37.3 & 0.029 & $\begin{array}{c}6.34 \\
(5.80)\end{array}$ & $\begin{array}{c}58.8 \\
(64.3)\end{array}$ & $\begin{array}{c}0.75 \\
(0.85)\end{array}$ & 22.4 & 0.72 & " \\
\hline 116 & & $\mathrm{C}$ & 43.8 & 0.022 & $\begin{array}{c}6.07 \\
(5.78)\end{array}$ & $\begin{array}{c}72.2 \\
(75.8)\end{array}$ & $\begin{array}{c}0.94 \\
(1.01)\end{array}$ & 24.7 & 1.24 & $"$ \\
\hline 117 & & $\mathrm{C}$ & 33.7 & 0.021 & 5.06 & 66.6 & 0.95 & 18.4 & - & 平坦河 床 or 遡上反砂堆 \\
\hline 118 & & $\mathrm{C}$ & 26.3 & 0.015 & 4.45 & 59.1 & 0.89 & - & - & 平坦河床 \\
\hline 119 & & $\mathrm{~B}$ & 17.8 & 0.022 & $\begin{array}{c}3.19 \\
(2.97)\end{array}$ & $\begin{array}{c}55.8 \\
(59.8)\end{array}$ & $\begin{array}{c}1.00 \\
(1.11)\end{array}$ & 15.2 & 0.60 & 流下反砂堆 \\
\hline 120 & & B & 30.5 & 0.064 & $\begin{array}{c}4.88 \\
(4.72)\end{array}$ & $\begin{array}{c}62.5 \\
(64.6)\end{array}$ & $\begin{array}{c}0.90 \\
(0.95)\end{array}$ & 11.2 & 1.75 & " \\
\hline 121 & \multirow{6}{*}{$1 / 178$} & $\mathrm{~B}$ & 34.0 & 0.019 & 6.53 & 52.1 & 0.65 & 27.4 & 0.49 & 砂 \\
\hline 122 & & $\mathrm{~B}$ & 23.8 & 0.0063 & 5.34 & 44.6 & 0.62 & 25.0 & 0.41 & $"$ \\
\hline 123 & & $D$ & 37.5 & 0.011 & 7.24 & 51.8 & 0.61 & - & - & 平坦河林 \\
\hline 124 & & $\mathrm{D}$ & 23.5 & 0.011 & 4.95 & 47.5 & 0.68 & 13.6 & 0.48 & 砂 堆 \\
\hline 125 & & B & 41.8 & 0.018 & 7.40 & 56.5 & 0.66 & 17.4 & 0.57 & $"$ \\
\hline 126 & & B & 25.8 & 0.0070 & 5.25 & 49.2 & 0.69 & 33.2 & 0.13 & " \\
\hline 127 & \multirow{4}{*}{$1 / 59$} & $\mathrm{~A}$. & 41.3 & 0.113 & 5.31 & 77.8 & 1.08 & 33.1 & -0.47 & 遡上反砂堆 \\
\hline 128 & & A & 45.8 & 0.137 & 5.69 & 80.5 & 1.08 & 64.4 & -1.57 & $"$ \\
\hline 129 & & A & 22.0 & 0.056 & 3.37 & 65.3 & 1.14 & 38.6 & -1.21 & " \\
\hline 130 & & $\mathrm{~B}$ & 32.3 & 0.038 & $\begin{array}{c}4.55 \\
(4.10)\end{array}$ & $\begin{array}{c}71.0 \\
(78.8)\end{array}$ & $\begin{array}{c}1.06 \\
(1.24) \\
\end{array}$ & 20.5 & 1.70 & 流下反砂堆 \\
\hline 139 & $1 / 51$ & A & 33.0 & 0.164 & 4.26 & 77.5 & 1.20 & 61.5 & -1.4 & Jump を伴 5 遡上反砂堆 \\
\hline 140 & $1 / 25$ & A & 16.0 & 0.262 & 3.76 & 42.6 & 0.70 & 132 & -1.5 & Chutes \& Pools \\
\hline 141 & $1 / 18$ & $\mathrm{D}$ & 12.0 & 0.259 & 2.97 & 40.4 & 0.75 & 99.4 & -2.3 & " \\
\hline 142 & $1 / 18$ & $\mathrm{D}$ & 25.0 & 0.587 & 4.64 & 53.9 & 0.80 & 175 & -1.3 & $"$ \\
\hline
\end{tabular}

（）内の数值は剶離を考虑した場合

\section{3. 流下反砂堆}

$F_{r} \geqq 1.0$ の流れであっても水理条件, 河床材料条件 によっては水面波と河床波は同位相ではあるが，市流に 移動する文砂堆（流下反砂堆）が発生する. 流下反砂堆 についての研究は著者らの知る限り見当たらず，わずか に文献 1)，2）で実験水路でのみみられるといら記述が ある・

一般に, 三次元河床波では, 掃流力が増すにつれて河 床形態が砂堆 $\rightarrow$ 平坦河床 $\rightarrow$ 反砂堆と変化する ${ }^{1), 2)}$. 一 方, 二次元河床波では, 砂堆 $\rightarrow$ 流下反砂堆 $\rightarrow$ 平坦河床 $\rightarrow$ 遡上反砂堆と変化し, 砂堆と平坦河床の間に流下反砂 堆が出現する. 後述の 図一17 が示すように流下反砂堆 の発生領域は狭く, 水理条件としてはフルード数が 1.0 付近の流れに集中する. フルード数が 1.0 付近であって も河床材料によっては流下反砂堆は明確には現われず, 掃流力の増加とともに, 砂堆 $\rightarrow$ 平坦河床 $\rightarrow$ 遡上反砂堆 といら変化をする場合がある. 河床材料としては粒径の 大きさが流下反砂堆の発生に影響する．実験水路の大き さ, 流れの三次元性も, 流下反砂堆の発生, 非発生に強
く関係する・

\section{（1）形状特性}

写真一4 は, 流下反砂堆の連続写真で 2.2 秒ごとに撮 影したものである. 図一2 は写真から測定した河床面, 水面および水深の流下方向変化を示す. 水深は, 河床波 頂上部の下流側で大きくなっており, 反砂堆というより はむしろ砂堆上の流れに似ている. 写真一5 は，流下反 砂堆の谷部の流れをアルミ粉末を用いて可視化し撮影し たものである・アルミ粉末の軌跡をみると下流側では流 れが剝離し渦巻いている.この剝離域の発生が流下反砂 堆の大きな特徵である. 可視化した写真から剝離領域を 求め, 剝離域の外縁を一つの流線と考え, この界面を基 準に水深它測り直す.このようにして求めた反砂堆上の 水深は表一1 の中に（）で示され，図一2 中には破線 で示されている.このとき，水深は河床波頂部で最大と なり射流で見出される水面と河床面の一般的な関係を満 たすことになる.この剝離琙の存在は河床波の伝播方向 に決定的な役割を果たす。すなわち, 剝離が生じている ために河床波上流側で洗掘され河床波上を掃流されてき た砂は, 河床波下流側に堆積し，その結果河床波は下流 
$4 \cdot 2$

4.4

4.6

$4.8 \mathrm{~m}$

t

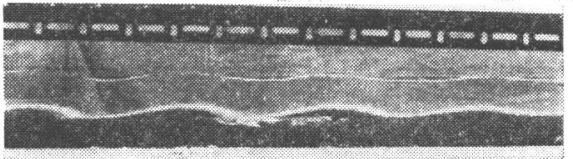

$\mathrm{t}+2.2 \mathrm{~s}$

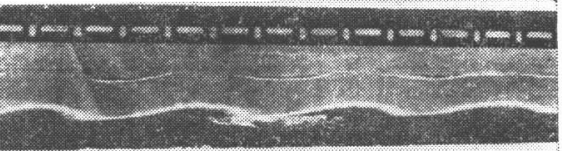

$t+4 \cdot 4 \mathrm{~s}$

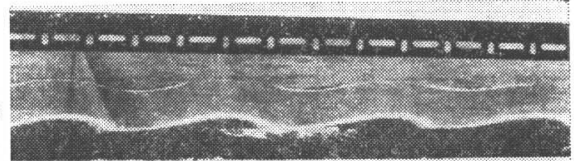

$t+6.6 s$

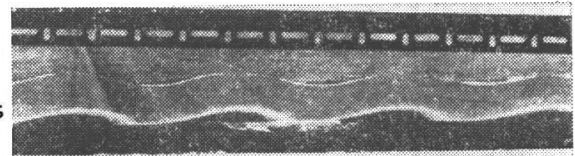

写真一4 流下反砂堆 (Run 120)
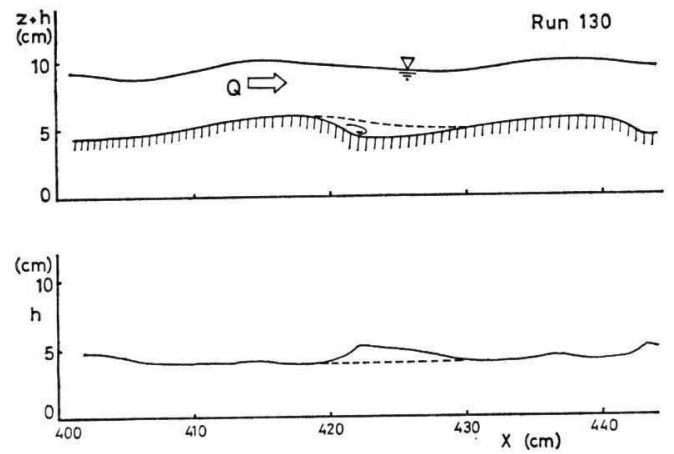

図一2 流下反砂堆の形状および水面形状

に移動する。この移動のメカニズムは砂堆のそれによく 似ており河床波下流側での流れの剝離が流下反砂の形状 と運動を支配している。

\section{（2）運動特性}

図一3 は流下反砂堆と水面波のそれぞれの頂点位置の 時間変化 (走時曲線) を示したものである.図中○印が 河床波, $\triangle$ 印が水面波である. 水面と河床面の位相はほ ぼ一致し, 河床波の波速も一定とみなし得る. 剝離域を 除くと流下反砂堆上の水深はほぼ一定となり,このため 給砂量一定（河床勾配一定）のもとではジャンプを伴う ことはない.しかし, 給砂量の変化に対して流下反砂堆 は極端に敏感に応答し形状が変化する．このようなとき には，一時的に水面にジャンプが現われたり，河床波が 消滅したりし，安定な流下反砂堆はみられない。
$\Rightarrow$ 流れの方向
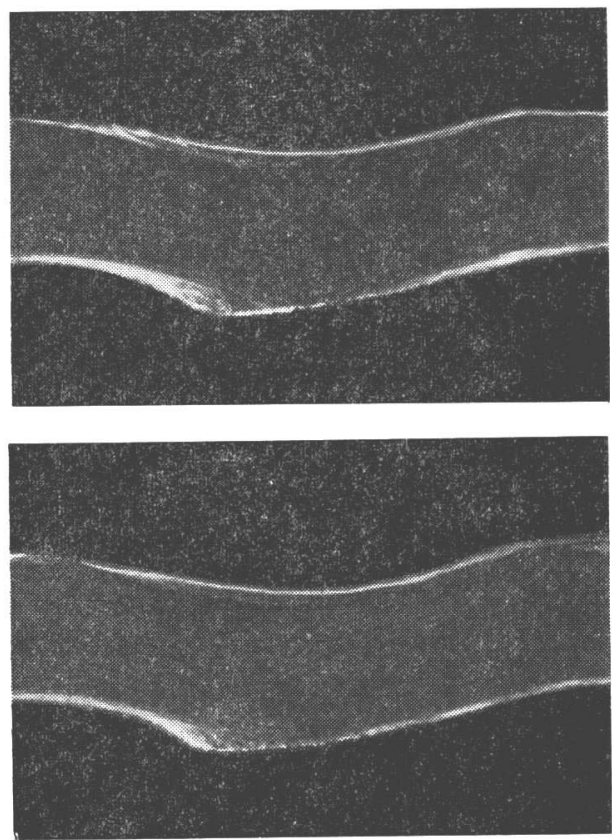

写真一5 アルミ粉末による剝離領域の可視化

(3) 波長

砂堆の波長は水深と密接な関係にあり 2), Yalin ${ }^{4}$ はこ れらの関係式として，

$$
L=5 h_{0}
$$

を提案している. 流下反砂堆はその形状特性, 運動特性 が砂堆のそれと非常に近いところから, 流下反砂堆の波 長も水深により規定されると考えられる. 流下反砂堆の 波長と平均水深との関係を示すと 図一4のようになり， 流下反砂堆の波長も砂堆と同様に水媣により規定され, 二次元流下反砂堆では, 波長と水深との関係はほぼ

$$
L=4 h_{0}
$$

で表わされる。

流下反砂堆は, 河床波と水面波の位相が一致している ことから反砂堆とよぶが, 流下方向の水深の変化が砂堆

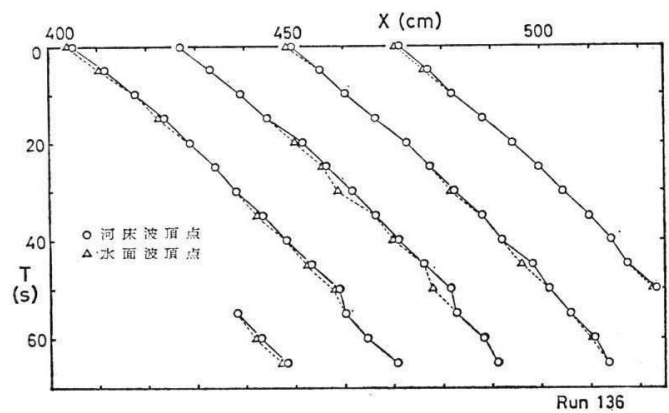

図一3 流下反砂堆の走時曲線 


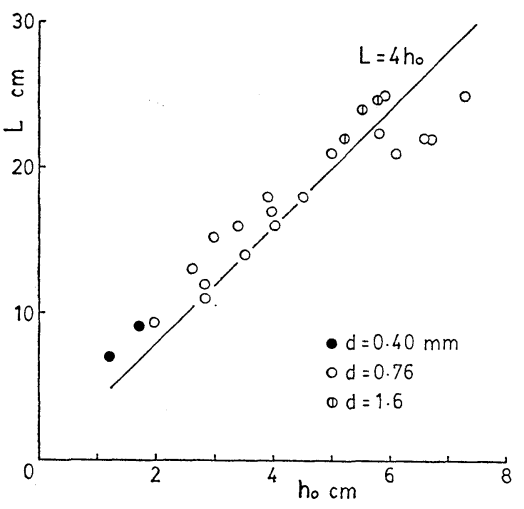

図一4 流下反砂堆の波長と水深の郦係

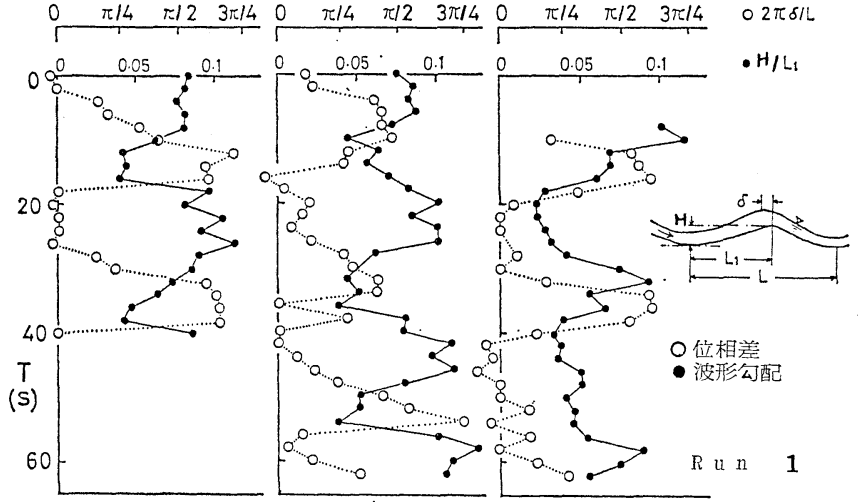

図一7 周期的なジャンプを伴う遡上反砂堆の位相差と波形勾配
の場合と同様であること，砂堆上の流れにみられるよう に河床波頂上部の下流側に剝離域が存在すること，伝播 方向が砂堆と同じ下流方向であること, 波長が砂堆と同 様に水深に規定されること，および流下反砂堆の発生フ ルード数, 掃流力が砂堆よりやや大きいが砂堆の発生条 件に近いことを考慮すると両者は本質的には同じもので あると判断される。

\section{4. 遡上反砂堆}

\section{（1） 周期的なジャンプを伴う遡上反砂堆の発達と 減衰}

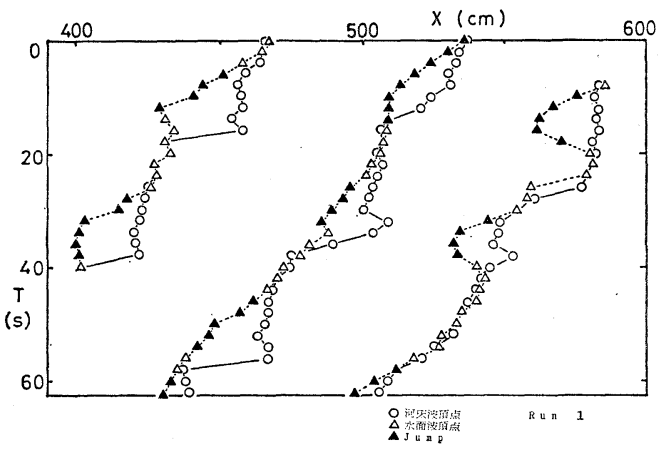

図一5 周期的なジャンプを伴う遡上反砂堆の走時曲線 upper flow regime でフルード数を増大させると遡上 反砂堆が発生する.フルード数が相対的に小さいうちは 遡上反砂堆上の水面波はジャンプを生ずることはない が，フルード数を増大させていくと水面波はジャンプを 生ずるよらになる。図一5，図一6 は周期的なジャンプ を伴う水面波と遡上反砂堆の走時曲線を示す. 図中 $\mathbf{\Delta}$ 印 は，水面にジャンプが生じていることを示す．これらの 図よりジャンプを生じているときには，水面波と河床波 の頂点の位置は大きくずれていること，いずれの条件に おいてもジャンプの発生がかなり周期的であることがわ かる.

図一7 は，水面波と河床波との位相差 $\left(2 \pi \frac{\delta}{L}\right)$ と河 床波上流側の波形勾配 $\left(H / L_{1}\right)$ の関係を示す. 周期的に ジャンプを伴うために, 位相差, 波形勾配ともにほぼ周 期的に変化する，位相差がほぼゼロのときに波形勾配は 増大してゆき，波形勾配が 0.1 程度になると位相差が大 きくなり，波形勾配は急激に減ずる．大きな位相差はジ ヤンプの発生により生ずることは明らかであり，河床波 の波高がジャンプの発生により規定されていることがわ かる. ジャンプを発生し始める時刻の河床波高と，最大 波高との関係を示したのが図一8である.この図より， 河床波の最大波高はジャンプを生じ始めるときの河床波 高にほぼ等しく，ジャンプの発生が最大波高を規定して いることがわかる。

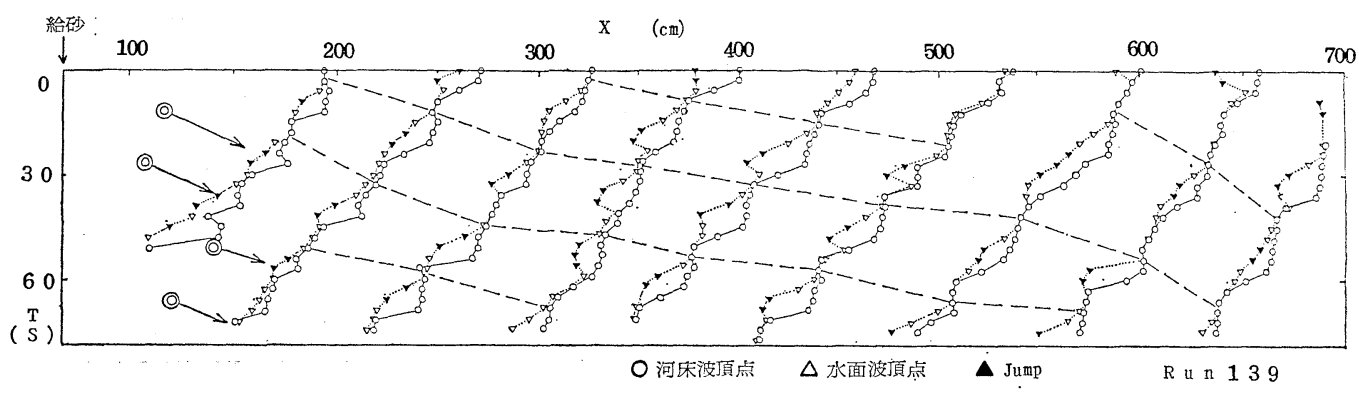

図一6 周期的なジャンプを伴う遡上反砂堆の走時曲線 


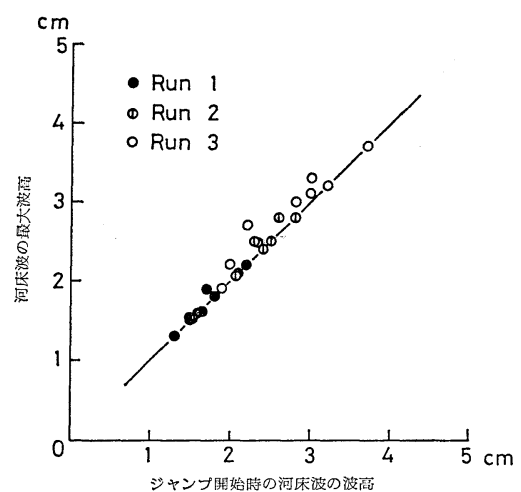

図一8 最大波高に及ぼすジャンプの影響

\section{（2）周期的なジャンプを伴う遡上反砂堆の波速}

河床波の平均波速は，図一5, 図一6 の河床波の頂点位 置の走時曲線の平均勾配で与えられる. 一方, 河床波の 波長は，同図で隣り合った河床波の頂点の間隔で与えら れる.いずれの実験条件においても平均波速, 波長はほ ぼ一定である.ジャンプを伴う反砂堆の瞬間波速が最大 になる時刻は, 図一 5, 図一6よりジャンプが消失する付 近の時刻である.この様子を説明したものが図一9であ る.上流から土砂を運搬してきた流速の大きな流れがジ ヤンプを生じている部分（B点）に達するとそこでは流 速が著しく小さいため, 土砂を $\mathrm{B}$ 領域に堆積させ, 新た な頂部を形成し始める (図一9 (c)〜 (e)).この位置は, ジャンプを生ずる前の頂点の位置（A点）に比べかなり 上流側にあたる.一方, ジャンプの下流側では掃流力が 大となっていること, 上流からの土砂供給がほとんどな いことにより，A点の位置付近の河床は急激に洗掘され る(図一- (d), (e)). したがって, 河床波の頂点の位置

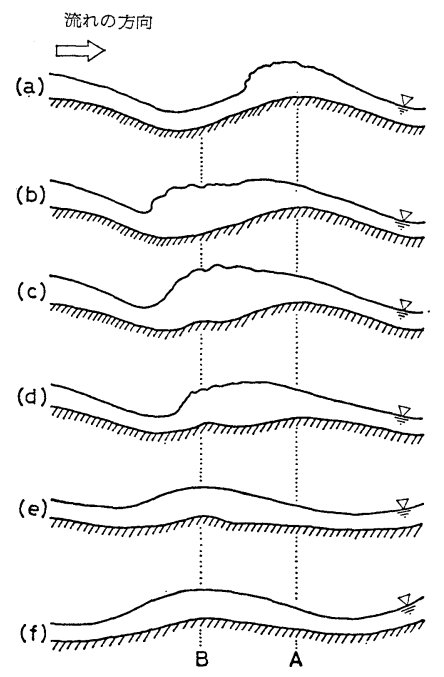

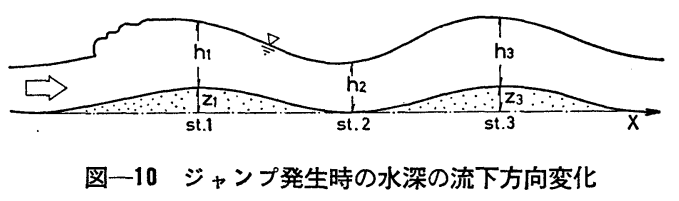

が急激に遡上することになる．このため，ジャンプが消 失する時刻付近で大きな波速が観察される.

ジャンプを伴う反砂堆を生じている流れを観察する と, ある場所でジャンプが起こるとわずかな時間遅れで その下流の反砂堆上にジャンプが現われる.このような 反砂堆上のジャンプが次々と下流に伝播していく機構, すなわちジャンプを伴ら反砂堆の出現を支配する境界条 件について調べる. 図一10 に示す 2 つの反砂堆上の流 れを考える. 反砂堆の伝播速度は, 流れの平均流速に比 して十分小さいので無視する. 流れは射流であるので上 流側の反砂堆の波高 $\left(z_{1}\right)$ が大きくなるにつれて頂点水 梁 $\left(h_{1}\right)$ も増大する. ジャンプが起こる直前には $h_{1}$ が 最大 ( $F_{r}$ 数最小), $h_{2}$ が最小 ( $F_{r}$ 数最大) の水深とな る. $z_{1}$ 上でジャンプが現われたとき, その下流の $z_{3}$ 上 にジャンプが起こるかどうかは, 位置 2 と位置 3 のフル 一ド数の相対的な大きさによって決まる. $z_{1}$ 上にジャ ンプが現われたとき水面波と河床波の閒に位相差が生じ このため河床波が崩壞し波高 $z_{1}$ は小さくなりジャンプ も消滅する. このときジャンプ中に貯留されていた流量 は解放され, 一時的に $z_{2}$ 上のフルード数 $F_{r_{2}}$ が増大す る注1).ジャンプが生じていないときの河床波高 $z_{1}$ と $z_{3}$ はほぼ同一であるのでその上の水深 $h_{3}$ も $h_{1}$ と同程度 となり，したがって $F_{r 3}$ はほぼ最小となっている. 一 方, ジャンプの消滅による流量増加によって $F_{r 2}$ はジャ ンプが生じていないときより大きくなり，このことが原 因となって $z_{3}$ 上にジャンプが現われる.

このようにしてまず上流でジャンプが起こると, ジャ ンプの発生, 消滅の過程がしだいに上流より下流に伝播 していくことになる．水路全体としては流れは射流であ るので流れの境界条件は上流端にある.したがって, ジ ヤンプを伝播させる要因も上流端にある.上流端の境界 条件(境界水深)に着目し, ジャンプを伴う反砂堆の伝播 メカニズムを実験により明らかにするため $35 \mathrm{~mm}$ カメ ラ 3 台と $8 \mathrm{~mm}$ 撮影機を併用し, 給砂位置から下流端ま で水路全体の河床波と水面波を観察した．再び図一6の ジャンプを伴ら反砂堆の走時曲線に着目する．緃軸は経 過時間, 横軸は上流端から水路に沿って測られた距離で

注 1）開水路流れでの流量の急増は, 流速と水深の増加とな って現われる. 急勾配流路床上での河床波 $z_{1}$ から $z_{2}$ へ の流れは加速流れであり,このような流れはポテンシャ 儿流的に振舞う。このとき, 底面の摩擦抵抗はほとんど 変化せず, 流量の増加は水深よりも流速の増大となって 現われる.したがって， $F_{r 2}$ が増大する. 


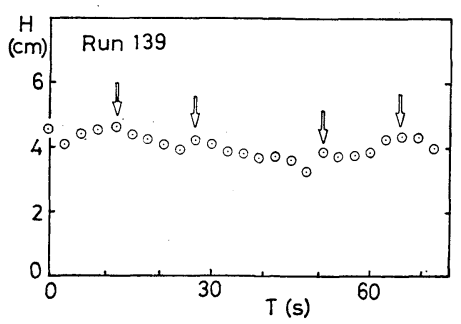

図一11 最上流の河床波上の水深変化

ある. 給砂は $x=50 \mathrm{~cm}$ 付近で行っている. ○印は河床 波の頂点, $\triangle$ 印は水面波の頂点を示す. 黒塗りの部分は ジャンプを起こしているときに対応する. 図中の破線は 関連する一連のジャンプを結んだもので, ジャンプが上 流から次々に伝播していく様子がわかる．遡上する反砂 堆のジャンプは給砂が一定であれば途中で消えることは ほとんどなく下流まで伝播する. 図一11 は水路流入端 付近を遡上通過する河床波上の水深の時間变化を示す. 最上流の河床波は下流から周期的に遡上してくるものに より形成される. 前述のように河床波頂上に最大水深が 現われたとき, その直下流の河床波上でジャンプが起こ る. 図一11 では口印で示した場所で水深は極大となっ ており，これらの位置を図一6上では@印で示した。( 印とり印の関係が示すように最上流の河床波上の水深に 極大が現われるとその直下流側でジャンプが起こってい る. すなわち, 最上流部の河床波上の流れが境界条件と なりその下流側にジャンプを引き起こし, それが次々と 下流に伝播していく・上流ジャンプの崩壊に伴ら下流へ の流量増加は下流へのジャンプの伝播を促す.

\section{（3）周期的なジャンプを伴う遡上反砂堆の最大波高}

反砂堆における波高限界は, ジャンプの発生と密接な 関係があることを前節で述べた. すなわち, ジャンプを 生ずるような河床波の波高が, 反砂堆の最大波高である と考えることができる. 本節では, 最大波高の算定を試 みる. 解析に際し次の仮定を行う。

（1）河床波上の流れは淮定常である.

（2）河床波の波形勾配は小さく，その上の流れの曲 率は無視できる.

座標系を 図一12 のように選ぶ. このとき水流の連続 式と運動方程式は

$$
\begin{aligned}
& B \cdot v \cdot h=Q=\text { 一定 } \ldots \ldots \ldots \ldots \ldots \ldots \ldots \ldots \ldots \ldots \ldots \ldots \ldots \ldots \ldots \\
& \frac{d}{d x}\left(\frac{\alpha v^{2}}{2 g}\right)+\frac{d}{d x}(z+h \cos \theta)+\frac{d h_{l}}{d x}=0
\end{aligned}
$$

となる.ここで， $h_{l}$ : エネルギー損失水頭であり，側壁 面と底面とでせん断力が異なることを考慮して式 (4) の 第 4 項を次のように表わす.

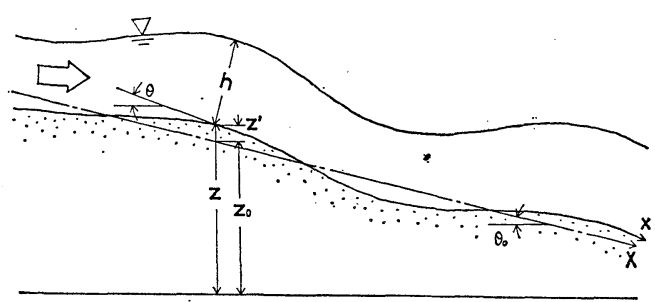

図-12 記号の定義

$$
\frac{d h_{l}}{d x}=\left(\frac{f_{b^{\prime}}}{h}+\frac{2 f_{w^{\prime}}}{B}\right) \cdot \frac{v^{2}}{2 g} .
$$

式 (3)，(5) を式 (4) に代入して整理すると, 次の水面 形方程式を得る.

$$
\begin{aligned}
& -\frac{d}{d x}\left(\frac{\alpha Q^{2}}{2 g B^{2} h^{2}}\right)-\cos \theta \frac{d h}{d x} \\
& =-\left(1+h \frac{d \theta}{d x}\right) \sin \theta+\left(\frac{f_{b}^{\prime}}{h}+\frac{2 f_{w}^{\prime}}{B}\right) \frac{Q^{2}}{2 g B^{2} h^{2}}
\end{aligned}
$$

波形勾配がきわめて小さい場合を考えているので, 次 の近似が成り立つ5).

$$
\left.\begin{array}{l}
z \rightarrow z_{0}+z^{\prime} \\
x \rightarrow X \\
\sin \theta \rightarrow \sin \theta_{0}-\frac{d z^{\prime}}{d X} \cos \theta_{0} \\
\cos \theta \rightarrow \cos \theta_{0} \\
\frac{d \theta}{d x} \rightarrow \frac{d}{d X} \sin \theta \rightarrow-\frac{d^{2} z^{\prime}}{d X^{2}} \cos \theta_{0}
\end{array}\right\}
$$

平均水路床勾配に対する等流水深を $h_{0}$ として,

$$
h=h_{0}+h_{1}
$$

とおく. $h_{0}$ からの変動 $h_{1}$ が非常に小さいと考え, 微小 項を無視すると $h_{1}$ に関する方程式が求まる.

$$
\begin{aligned}
& \left(\frac{\alpha Q^{2}}{g B h_{0}{ }^{3}}-\cos \theta_{0}\right) \frac{d h_{1}}{d X}=-\sin \theta_{0}+\frac{d z^{\prime}}{d X} \cos \theta_{0} \\
& +h_{0} \frac{d^{2} z^{\prime}}{d X^{2}} \cos \theta_{0} \cdot \sin \theta_{0} \\
& +\frac{Q^{2}}{2 g B^{2}}\left\{\frac{f_{b}{ }^{\prime}}{h_{0}{ }^{3}}\left(1-3 \frac{h_{1}}{h_{0}}\right)+\frac{2 f_{w^{\prime}}}{B h_{0}{ }^{2}}\left(1-2 \frac{h_{1}}{h_{0}}\right)\right\}
\end{aligned}
$$

$h_{0}$ 注平均水路床勾配に対する等流水深であるので, $h_{0}$ に関する式は

$$
\frac{Q^{2}}{2 g B^{2} h_{0}{ }^{2}}\left(\frac{f_{b}{ }^{\prime}}{h_{0}}+\frac{2 f_{w}{ }^{\prime}}{B}\right)=\sin \theta_{0}
$$

となる. 式 (10) を式（9）に代入して整理すると，

$$
\left(F_{0}-1\right) \frac{d h_{1}}{d X}=\frac{d z^{\prime}}{d X}+h_{0} \frac{d^{2} z^{\prime}}{d X^{2}} \sin \theta_{0}-M \frac{h_{1}}{h_{0}}
$$

となる.ここで

$$
\left.\begin{array}{l}
F_{0}=\frac{\alpha Q^{2}}{g B^{2} h_{0}{ }^{3} \cos \theta_{0}} \\
M=\frac{Q^{2}}{2 g B^{2} h_{0}{ }^{2} \cos \theta_{0}}\left(3 \cdot \frac{f_{b}{ }^{\prime}}{h_{0}}+4 \cdot \frac{f_{w^{\prime}}{ }^{\prime}}{B}\right)
\end{array}\right\} \cdots
$$


いま，河床波形状および水面形状を，それぞれ

$$
\begin{aligned}
& z^{\prime}=a(t) \sin k(X-c t) \cdots \cdots \cdots \\
& h_{1}=h_{10}(t) \sin \{k(X-c t)+\phi\}
\end{aligned}
$$

で表わす. 式 (13),(14) を式 (11) に代入して $h_{10}(t)$ を 求め, その結果を式 (14) に代大して整理すると水深は,

$$
h=h_{0}+a(t) A \sin \{k(X-c t)+\phi\}
$$

のようになる.ここで，

$$
A=k h_{0} \sqrt{\frac{1+\left(k h_{0} \sin \theta_{0}\right)^{2}}{M^{2}+\left\{k h_{0}\left(F_{0}-1\right)\right\}^{2}}}
$$

$\phi=\arccos \left[\frac{\left\{k h_{0}\left(F_{0}-1\right)-M k h_{0} \sin \theta_{0}\right\}}{\sqrt{\left\{M^{2}+k^{2} h_{0}^{2}\left(F_{0}-1\right)^{2}\right\}\left\{1+\left(k h_{0} \sin \theta_{0}\right)^{2}\right\}}}\right]$

である・

長方形断面の場合，限界水深は次式で与えられる.

$$
h_{c}=\sqrt[3]{\frac{\alpha Q^{2}}{g B^{2}}}
$$

河床波上の最大水深は式 (15) より次式で与えられる.

$$
h_{\text {max }}=h_{0}+a(t) A
$$

河床波が反砂堆で，かつ水面にジャンプを生じていない ときには，流れは射流状態に保たれている. 河床波が発 達し, やがて限界水深を越える地点が存在すればその地 点でジャンプを生ずると考えられる. したがって, ジャ ンプの発生条件は近似的に,

$$
h_{c}<h_{\max }
$$

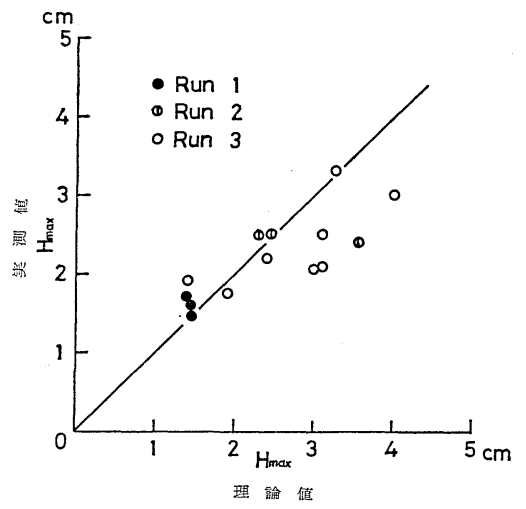

図一13 周期的なジャンプを伴う遡上反砂堆の最大波高
で与えられる. 限界の状態では

$$
h_{c}=h_{\max }=h_{0}+a(t) A
$$

となり, 反砂堆の最大振幅は

$$
a_{\max }=\frac{h_{c}-h_{0}}{A}
$$

で与えられる。

式 (16) は $M \ll k h_{0}, k h_{0} \sin \theta_{0} \ll 1$ の場合では近似 的に

$$
A=\frac{1}{F_{0}-1}
$$

となり，式 (22)，(23) から最大波高が求まる.

$$
H_{\max }=2 a_{\max }=2\left(h_{c}-h_{0}\right)\left(F_{0}-1\right)
$$

河床波の最大波高の実測值と式 (24) の比較を 図-13 に示す. 理論式中の平均水深 $h_{0}$ として, 水面波の山部 と谷部の水深の平均值を用いた. ジャンプを伴う河床波 という非定常性の強い現象にもかかわらず, 式 (24) は おおむね実験結果を説明している.

\section{Chutes \& Pools}

ジャンプを伴う反砂堆では, ある地点のジャンプがそ の下流の河床波上にジャンプを誘発するまでに若干の時 間を要することを知った. このような時間遅れは流れの フルード数を高めていくにつれて小さくなり, やがて水 路全体にわたって 同時にジャンプが現われるようにな る. このように定常的にジャンプを起こしている河床波 を Chutes \& Pools とよぶ.

Chutes \& Pools の 写真一3 から明らかなように, 水 面波の頂点は河床波の最大高さの位置と一致するわけで はなく，水面波の頂点がどこに現われるかを判定するこ とは困難である.このため河床波頂点のみの走時曲線を 図一14 に示す. Chutes \& Pools は一定の形を保ち一定 速度で上流に移動する.この理由は次のように考えるこ とができる. Pools 部の区間は短く, かつ激しく混合し ているため上流の Chutes 部で洗掘, 輸送されてきた砂 はほぼ一様に Pools 部に堆積する. Chutes 部と Pools

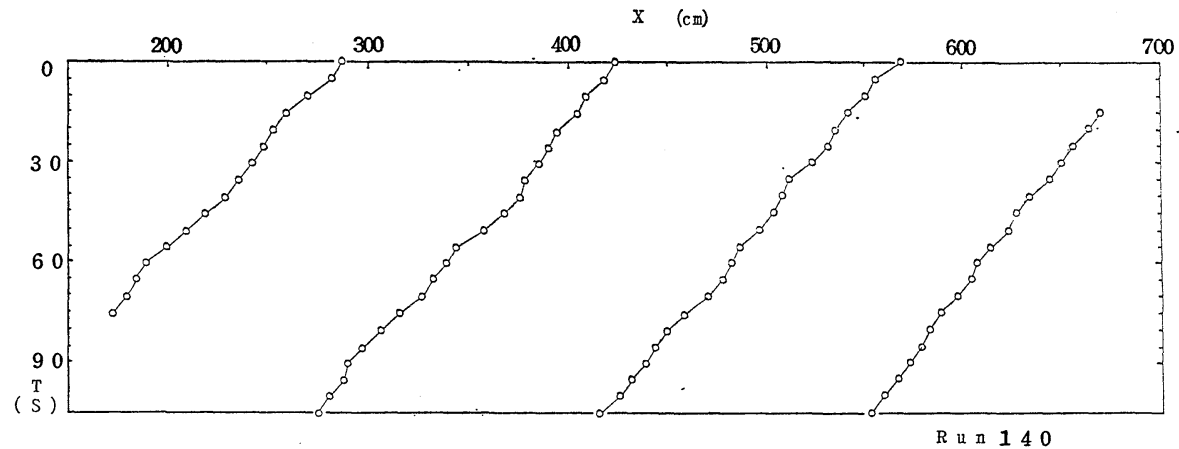

図一14 Chutes \& Pools の走時曲線 
部の洗掘, 堆積の平衡過程が水路の全区間にわたって起 こることにより河床波が一定形状, 一定速度で遡上す る.これに対し, ジャンプを伴ら遡上反砂堆では, 発達 過程と崩壊過程の洗掘, 堆積の強さの違いが移動速度の 時間的な差となって現われる.

Chutes \& Pools の最大波高は遡上反砂堆と異なりジ ヤンプが最大波高を決める原因とはなり得ない。この河 床形態は洗掘と堆積が平衡しており, 流量条件の変化に より掃流力が增加するとある場合にはその掃流力に相当 する平衡高さとなり，他の場合には河床波がすべてフラ ッシュされ平坦床へ移行する. したがって Chutes \& Pools の最大波高は一義的に決まらず，河床材料，特に 粒径の影響を強く受ける.

\section{6. 各河床波の特性の比較}

3.〜5. で各河床波の特性を述べたが，さらに次の 3 点に着目して総合的に比較検討する.

（1）形状特性と運動特性

(2) 粒径の効果

（3）河床波を規定する境界条件

\section{（1）形状特性亡運動特性}

砂堆は上流が緩やかで下流が急な三角形形状をしてい るのに対し, 遡上反砂堆, Chutes \& Pools はほぼ正弦 波形をなしている．流下反砂堆は河床波下流側で剥離を 起こしており，形状としては波形勾配のやや大きい砂堆 状ではあるが，剝離流線を考慮した河床形状は正弦波形 に近いものである．各河床波の運動様式を考えると，砂 堆・流下反砂堆は河床波下流側の剝離域の存在が重要な 役割を果たす.これらの河床波では上流面で洗掘されて きた砂が剝離域に大部分堆積するため，河床波が下流に 移動する. 一方, 遡上反砂堆や Chutes \& Pools では河 床波の上流側に現われるジャンプが重要な役割を果た

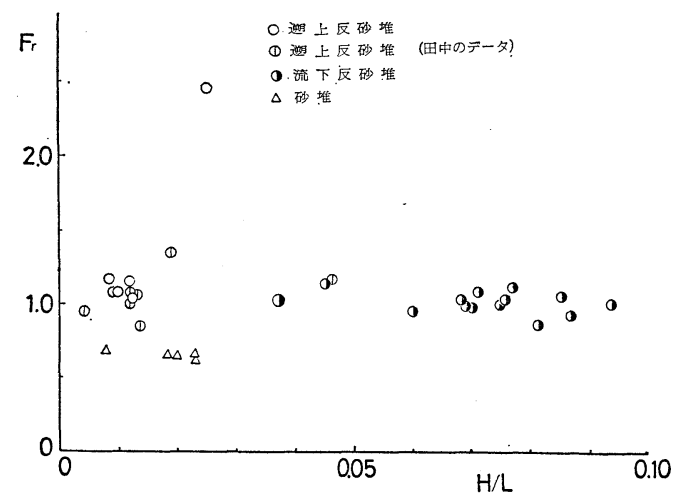

図-15 種々の河床波の波形勾配
す. 河床波の下流側は加速域のため河床は洗掘される が，上流から輸送されてくる砂はジャンプ内に堆積す る.この結果, 砂粒は下流に輸送されるが, 波形は上流 に伝播する.

流下反砂堆と遡上反砂堆は, 河床面と水面の位相が一 致することを除いて運動，形状特性に大きな差がある. 図一15 は，各河床波の波形勾配をフルード数の関数と して示す.いずれも二次元水路での実験データで本実験 と田中の実験9)からなる. 砂堆は $H / L \approx 0.02$ 注 2$)$, 遡上 反砂堆 0.1 の範囲にある. 遡上反砂堆流下反砂堆に比べて波 形勾配は小さい．これは，最大波高にはほとんぞ差がな いが，前者が後者より波長が大きいためである.

\section{（2）粒径の効果}

Gilbert $^{6)}$ の研究以来, 同一の水理条件でも河床材料, 水路の規模により形成される河床形態が異なることが指 摘されてきた. upper flow regime の二次元河床波にお いても粒径の影響が強く認められる.用いた実験水路で は, 表一1 が示すようにA砂では流下反砂堆は発生しに くく，B砂，C砂などの粒径の大きなものでは遡上反砂 堆は発生しにくい，一方，D砂では水理条件を変化させ ることによって両方の河床形態が発生する. Guy ら 実験水路 (幅 $0.6 \mathrm{~m}$ と $2.0 \mathrm{~m}$ ) では, 平均粒径 $0.95 \mathrm{~mm}$ の砂磻でも遡上反砂堆が発生している.このように水路 の規模が異なれば同一粒径の河床材料でも河床形態は異 なる，一般に，河床波を規定するものとして無次元掃流 力, 粒径と水深の比の関係を用いることが多いが ${ }^{21}$, 流 れの三次元性に関係する水路幅と水深, 水路幅と粒径の 相対的な関係む重要である.

\section{（3）安定した河床波を規定する境界条件}

河床勾配，水路幅が一定の条件のもとで一定流量が流 れると流れの全領域にわたって安定した河床波が現われ る.これらの量のいずれかが変動すると，ある種の河床 波は敏感に応答し, 流路全域にわたって河床波は変形す る. 一方, 他の種の河床波では変化の影響は上流より緩 やかに伝わり流路全体に及ぶにはかなりの時間を要す る. 本節では, 河床波上の流れの境界条件の位置と河床 波の伝播する方向の関係が安定した河床波の出現を支配 することを示す。

一定量の給砂によって安定な反砂堆が形成されている 流れで, 突然給砂が停止された後の反砂堆の変形を考え てみる．給砂の停止により上流の河床勾配は徐々に緩や かになるが，下流への砂の輸送量は急激には変化しない

注 2) 砂堆の $H / L$ は掃流力によってかなりの範囲 $(0.01$ 0.06）をとるといわれている. 
ために中，下流の河床勾配の変化はきわめて小さい，射 流の場合には, ある位置の水深はそれより上流水深で決 まっており，この関係は流れの全域で成立する.したが って, 遡上反砂堆上の流れの境界条件は上流端にある. 上流部の河床勾配が変化しても, その位置より下流の勾 配変化の小さなところから安定した大きさの反砂堆が遡 上してくるため，この安定な河床波上の流れを規定する 境界条件はやや下流に移動するだけでこの位置より下流 では安定な河床波が継続して現われる. 遡上反砂堆の場 合には, 上流に境界条件があり河床波の伝播方向も上流 であるため, 流路が長ければ河床勾配が全域変化してし まうほどの時間が経過しない限り, 少なくとも下流部で は安定した遡上反砂堆をみることができる.

流下反砂堆上の流れの境界条件も上流端にあるが, 河 床波は下流に伝播するため, 上流での境界条件が変化す ると流砂量はただちに変化し，その結果河床波の特性も 流下方向に変化する.すなわち, 給砂条件の変化により 上流境界条件が変化すると流下反砂堆は敏感に応答し, その変化はかなりの速度で下流に伝わる. 流路内には 種々の大きさの流下反砂堆が現われ，時には河床波が消 滅したり, 異常に波形勾配が増してジャンプを起こすこ ともある. 給砂量が一定であるように給砂したときのみ 上流の境界条件は一定となり, 規則正しく, 大きさがそ ろった安定な河床波が流下する。

一方, 砂堆を形成する流れは常流であるため, 砂堆上 の流れの境界条件は下流端にある. 砂堆による河床の擾 乱は下流に伝わり，水理条件に応じた一定の周期をもっ て下流端を通過していく，境界条件が下流端にあり，擾 乱の伝播する方向も下流であるため, 遡上反砂堆と同椂 に安定な砂堆が水路内に生ずることになる。したがっ て, 砂堆の場合には給砂が行われなくても, 水路が十分 長ければ上流から土砂が輸送されてくるため, 長時間に わたって下流部には規則正しい安定な砂堆をみることが できる.

以上総合すると, 安定な河床波の形成には流れの境界 条件を規定する位置と河床波の伝播方向が密接に関係す る. 特に流下反砂堆の場合には給砂量を一定に保つこと が安定な河床波形成のために必須の条件であり, 給砂量 が変化すれば河床波を乱してしまうことに注意を要す る. 以上は給砂量の変化，すなわち勾配が変化するとき の議論であった. しかし給砂量一定のままでも, 流量が 時間的に変化した場合には流砂量と給砂量が平衡しなく なり，前述の議論はこの場合にも成立する. 非定常下で の流砂実験ではこのことを念頭におく必要がある.

\section{7. 二次元河床波と三次元河床波の比較と 領域区分図}

二次元河床波と三次元河床波の明確な相違点として次 の 2 点が考えられる. 第一は, 流下反砂堆の発生であ る. 二次元水路では容易にみることのできる流下反砂堆 は, 三次元的流動様式をとる水路では発生しにくいよう である注3).これは, 三次元的流路での流下反砂堆の形 状が三次元的となるために二次元流路ほど明確には識別 できないためであろう.また, 流下反砂堆は上流境界条 件の変化によってすぐに河床波が変形し, 破壊されやす いことも原因と思われる.

第二の相違点は遷移領域での河床形態に見出すことが できる. 二次元流路では遷移河床は平坦河床に限られ る. しかし, 三次元水路では平坦河床, 砂堆, 反砂堆な どさまざまな河床形態が重畳し現われたり消えたりす る7). この理由は, 三次元水路では流れの自由度が大き いために平均水理量からずれる場所があちこちに生じ, upper flow regime になったり, lower flow regimeに なったりするために遷移領域では種々の河床波が現われ るものと考えられる.

次に, 二次元河床波と三次元河床波の統一的な領域区 分を考えてみる.

河床波の領域区分では, 側壁の影響を除いた径深 $R_{b}$ を用いて算定した無次元掃流力比 $\tau_{*}$ と, $R_{b}$ と粒径の比 $R_{b} / d_{50}$ を両軸に選ぶことが多い2). 確かに砂の輸送と直 接的に関係し河床波の形成に寄与寸るのは底面の有効摩 擦力で $\tau=\rho g R_{b} I$ より算定するのは合理的である. し かし，河床波の大きさを支配する長さのスケールとして $R_{b} / d_{50}$ を採用する理由は明確でないように思える. な ぜならば， $R_{b}$ が実際にどのような長さをもち, どのよ らな機構で河床波の大きさを規定しているのか物理的に 不明なためである. 本来, 径深は三次元的流れの平均せ ん断力を換算するために導入されたもので, せん断力と のかかわりで径梁を用いるのは正しいが，長さの代表值 として水深に代えて径深を用いる根拠は薄い. 特に本研 究のように急勾配移動床での upper flow regime での 河床波には水面と河床面との相互作用が強く影響し, 流 れに及ぼす側壁抵抗の有無に無関係に水深 $h$ の大きさが 決定的に重要となる.したがって河床波を規定する長さ のスケールとして $h / d_{50}$ を採用する必要がある.

Garde $ら^{8)}$ は多くの三次元データと実河川データを用

注 3）三次元流れでも流下反砂堆と特性のよく似たものの発 生が報告されている[文献 7）の中の写真 I 43, Guy ら はこれを standing wave とよんでいる]. すなわち, 流 下反砂堆々同様に水面波と河床波の位相は一致している が, 河床波谷部で水深が大きくなっている. 
い $I / s \sim R / d_{50}$ で整理し 河床形態の領域区分図を作製し た.ここに，I は河床勾配， $s$ は砂の水中比重である. この区分図に本実験で得られた二次元河床波の実測値を 記入したものが図一16 である. Garde らの横軸 $R / d_{50}$ の代わりに $h / d_{50}$ を用い整理した. 遡上反砂堆, Chutes \& Poolsの実測值は Garde らの区分図で説明できるが, 流下反砂堆は遡上反砂堆と遷移領域の間にプロットされ る. 一方, 砂堆の測定值はすべて遷移領域に含まれてお り，田中" が指摘したように砂堆の区分には問題がある ようである。

以上のように Garde らの区分図は二次元データに対

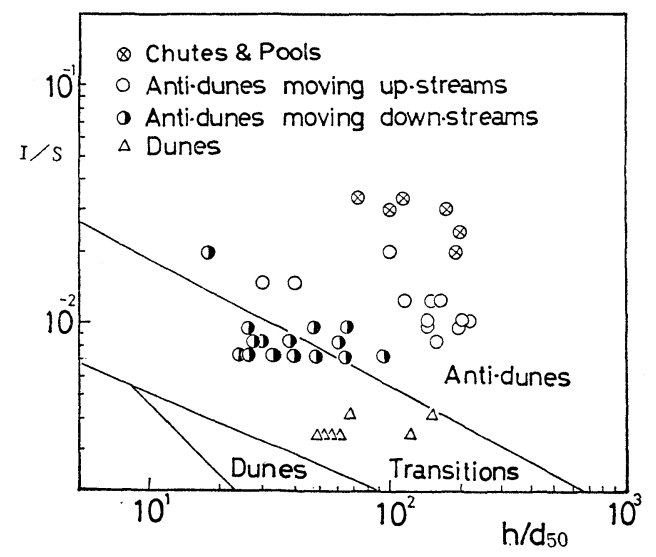

図一16 Garde らの領域区分法と二次元データの比較

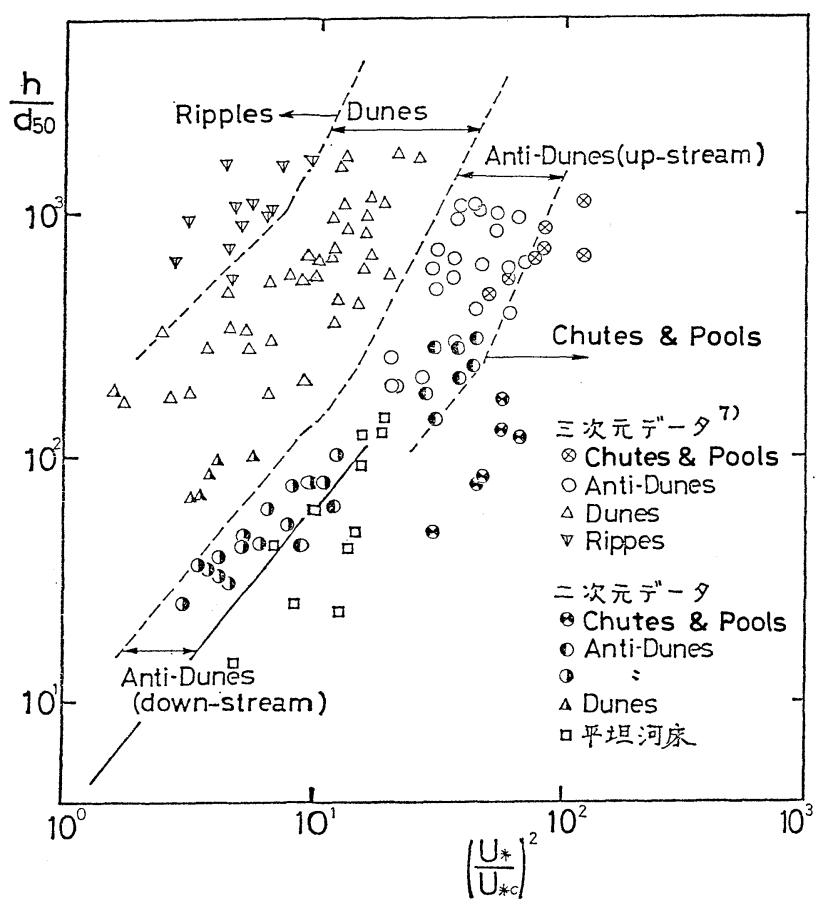

図一17領域区分図
乙遷移領域が広く流下反砂堆掞よび砂堆の領域を的確に は表現し得ていない．そこで二次元河床波に対し $\left(u_{*}\right)$ $\left.u_{* c}\right)^{2} \sim h / d_{50}$, 三次元河床波に対し $\left(u_{*} / u_{* c}\right)^{2} \sim h / d_{50}$ で 整理しプロットしたものを図一17 に示す注4)。この方法 によれば，二次元，三次元河床波は統一的に区分でき， 河床形態が砂漣, 砂堆, 流下反砂堆, 平坦河床, 遡上反 砂堆, Chutes \& Pools の 6 領域に区分できる.この区 分法は, 芦田・道上 ${ }^{11}$ が抵抗予測のために $\tau_{*} \sim R / d$ 平 面上で lower flow regime, transitions, upper flow regime に河床形態を区分したものと同じものとみなす ことができる. その後, 山本 ${ }^{12}$ も実河川の河床波データ をも含めて同様な検討を行っている．本研究で新たに 図一17の領域区分図を検討した理由は，よく制御され た二次元河床波実験によって芦田らの結果の確認，upper flow regime の河床波発生領域の詳細な検討を行う ことにある。

\section{8. 結 論}

upper flow regime に扝ける河床波の力学的・運動学 的特性を解明する目的で実河川の河床波を単純化した二 次元河床波を実験的に調べた. 三次元的河床波の挙動は さらに複雑ではあるがその力学的・運動学的特性は本質 的には変わらないものと考元られる. 今後は二次元河床 波と三次元河床波の相似性, 相反性を調べるために, 流 路幅を変化させ，二次元河床波はどの範囲まで持 続されるか，流れの三次元性，河床波の三次元性 がどのように現われ始めるか，水路幅が河床波に どのような影響を与えるかを詳細な実験によって 検討し, 本研究で得られた成果の適合性の範囲を 明確にするつもりである.

本研究より明らかにされたことを以下に要約す る.

（1）二次元流路ではある水理条件，河床材料 のもとで流下反砂堆が形成される. 流下反砂堆上 の流れは河床波の下流側で流れが剝離しているた め谷部で水深が大きく, 山部で小さい砂堆上の流 れと似ている.このことは, 流下反砂堆上の流れ の抵抗則が砂堆上の流れの抵抗則との類似性を意 味している.このような剝離域の存在は，流下反 砂堆の進行方向を決める決定的な役割を果たす. 剝離域を死水域とみなせば，流下反砂堆上の流れ は upper flow regimeの流れと一致する。

（2）規則正しい二次元形状をもつ流下反砂堆

注 4）摩擦速度 $u_{*}$ は, 三次元河床波に対し $\sqrt{g R I}$, 二次元河床波に対し径深分離法 ${ }^{102}$ で求めた径深 $R_{b}$ を用いた $\sqrt{g R_{b} I}$ より算定している. 
上の流れはジャンプを起こすことなく一定速度で移動す る.

（3）流下反砂堆の波長は，砂堆の波長と同様に水深 によって規定される. その関係はほぼ $L=4 h_{0}$ で表わさ れる. 流下反砂堆の形状, 運動特性からみて, 流下反砂 堆は砂堆と本質的に類似のものとみなし得る.

（4）ジャンプを伴う遡上反砂堆の発達・減衰は水面 波と河床波との位相差と密接な関係にあり，位相差が小 さいとき発達過程にあり, 位相差が大きいとき減衰過程 にある.ジャンプの発生は, 両者の位相差を急激に増大 させる

（5）ジャンプを伴う遡上反砂堆の最大波高はジャン プの発生によって規定される. ジャンプの発生条件を理 論より求めることによって最大波高の算定が可能となっ た.

（6）ジャンプを伴う遡上反砂堆では, 上流部で起こ ったジャンプが短い時間間隔のもとに次々と下流に伝播 する.このようなジャンプの伝播機構が明らかになっ た.

(7) Chutes \& Pools は Pools 部に定常的なジャン プを伴うが，河床面および水面はほぼ一定の速度で遡上 する. 二次元 Chutes \& Pools では Chutes 部で洗掘さ れた砂が直下流の Pools 部に堆積し規則正しい正弦波形 を呈する.

（8）河床波が規則正しく安定な形状を有するかどう かは河床波上の流孔の境界条件と河床波の伝播方向と密 接に関係する. 流下反砂堆は, 砂堆, 遡上反砂堆, Chutes \& Pools に比して上流境界条件の変化に特に敏感であ り, 上流勾配が変化するとその形状, 速度はすぐに変化 する.

（9）二次元河床波の場合には $h / d_{50} \sim\left(u_{*} / u_{* c}\right)^{2}$, 三 次元河床波の場合には $h / d_{50} \sim\left(u_{*} / u_{* c}\right)^{2}$ で区分するこ
とにより二次元，三次元河床波の発生領域を統一的に説 明できる.

本研究の一部は, 文部省科学研究費, 自然災害科学特 別研究 (1)「扇状地に打ける洪水, 土砂災害の発生とそ の防止軽減に関する研究」(代表者：京大 芦田和男教 授)の援助によって行われたものである. 記して謝意を 表する.

\section{参考文 献}

1) Task Force on Bed Forms in Alluvial Channels of the Committee on Sedimentation: Nomenclature for bed forms in alluvial channels, Proc. ASCE, HY 3 , May, 1966.

2）移動床流れにおける 河床形態と粗度, 水理委員会移動床 流孔の抵抗と河床形状研究小委員会, 土木学会論文報告 集, 第 210 号, 1973.

3）福岡捷二・山坂昌成：跳水を伴う反砂堆，第 16 回自然荻 害科学総合シンポジウム講演論文集, 1979.

4) Yalin, M.S. : Geometrical properties of sand waves, Proc. ASCE, HY 5, Sept., 1964.

5）岩在義朗：水理学, 朝倉書店, 1968.

6) Gilbert, G.K. : The transportation of debris by running water, U.S. Geological Survey, Professional Paper, 86, 1914.

7) Guy, H.P., D.B. Simons and E.V. Richardson : Summary of alluvial channel data from flume experiments, 1956 61, U.S. Geological Survey, Professional Paper, 1966.

8) Garde, R.J. and R. Raju : Regime criteria for alluvial streams, Proc. ASCE, HY 6, 1963.

9）田中祐一郎：Anti-dune に関する実験的研究，京大防災 研年報, 第 13 号 B, 1970.

10) Einstein, H.A. : The bed-load function for sediment transportation in open channel flows, U.S. Dept. Agriculture, Soil Conservation Service, Tech. Bull. No. 1026, 1950.

11）芦田和男 - 道上正䂓 : 移動床流れの抵抗と掃流砂量傜関 寸る基礎的研究, 土木学会論文報告集, No. 206, 1972.

12）山本晃一：相似律の観点加ら見た移動床の水理 [II], [III]，士木研究所資料，1074，1154，1976.

(1981.2.3. 受付) 